Case Reports in
Gastroenterology
Case Rep Gastroenterol 2021;15:142-146

DOI: 10.1159/000512422

Published online: February 4, 2021

(C) 2021 The Author(s)

Published by S. Karger AG, Base

www.karger.com/crg

This article is licensed under the Creative Commons Attribution-NonCommercial 4.0 International License (CC BY-NC) (http://www.karger.com/Services/OpenAccessLicense).

Usage and distribution for commercial purposes requires written permission.

\title{
Wilson's Disease Presenting in Late Adult Life
}

\author{
Wafa AIDhaleei Maryam AlAhmad Ibrahim Alhosani \\ Gastroenterology Department, Sheikh Shakhbout Medical City, Abu Dhabi, UAE
}

\section{Keywords}

Wilson's disease $\cdot$ Liver $\cdot$ Copper $\cdot$ Genetic testing

\begin{abstract}
Wilson's disease (WD) is an autosomal recessive disease affecting the copper metabolism resulting in various clinical presentations. Diagnosis includes the presence of low serum copper and ceruloplasmin concentrations, increased urinary copper excretion, and/or increased hepatic copper concentrations. Yet, genetic testing remains diagnostic. Management includes copper chelating agents and liver transplant in advance cases. We report a case of WD presenting with liver function impairment in late adult life and started on treatment. Therefore, early diagnosis and treatment of WD can prevent related complications.
\end{abstract}

(C) 2021 The Author(s)

Published by S. Karger AG, Basel

\section{Introduction}

Wilson's disease (WD) is an autosomal recessive disease of the copper metabolism affecting ATP7B gene [1]. WD results in the accumulation of copper in various organs, such as the liver, brain, kidneys, and cornea, resulting in a variety of clinical symptoms including hepatic disease, neuronal degeneration of the brain, and Kayser-Fleischer (KF) rings at the corneal limbus [2]. Diagnosis of WD includes, but is not restricted to, the presence of low serum copper and ceruloplasmin concentrations, increased urinary copper excretion, and/or increased

\begin{tabular}{|c|c|}
\hline 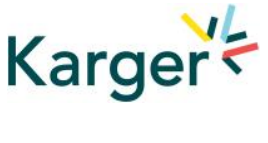 & $\begin{array}{l}\text { Maryam AlAhmad } \\
\text { Arab Board and Jordanian Board in Internal Medicine } \\
\text { Gastroenterology Department, Sheikh Shakhbout Medical City } \\
\text { Abu Dhabi } 00000 \text { (UAE) } \\
\text { maryam.alahmed@live.com }\end{array}$ \\
\hline
\end{tabular}




\section{Case Reports in Gastroenterology}

Case Rep Gastroenterol 2021;15:142-146 DOI: $10.1159 / 000512422$

(c) 2021 The Author(s). Published by S. Karger AG, Basel www.karger.com/crg

AlDhaleei et al.: Wilson's Disease Presenting in Late Adult Life

hepatic copper concentrations [3]. However, positive molecular testing remains diagnostic [1]. Treatment of WD mainly consists of using chelating agents to reduce the copper accumulation in the body. Copper chelating agents include penicillamine, trientine, and/or zinc [4]. Liver transplantation can be considered in advanced cases [1]. Here, we report a case of a patient with liver function impairment in late adult life.

\section{Case History}

A 49-year-old nonalcoholic and nonsmoking man, known to have dyslipidemia, was referred to the Gastroenterology clinic due to elevated liver function tests and abnormal liver ultrasound (US) report. He reported heartburn and was found to have a positive urea breath test. Triple therapy for Helicobacter pylori eradication was given for 7 days; amoxicillin $1 \mathrm{~g}$ twice daily, clarithromycin $500 \mathrm{mg}$ twice daily, and omeprazole $20 \mathrm{mg}$ twice daily.

He denied fever, yellowish discoloration of sclera, weight loss or loss of appetite, tremors or involuntary movements, nausea, vomiting, vomiting blood, abdominal distension, change in bowel habits, the passage of fresh blood per rectum, or having a blackish tarry stool. He denied the use of herbal medications or recreational drugs. He denied any family history of liver disease or gastrointestinal malignancy.

His initial investigations showed total bilirubin $6.1 \mu \mathrm{mol} / \mathrm{L}$, direct bilirubin $2.6 \mu \mathrm{mol} / \mathrm{L}$, ALP 69 IU/L, AST 47 IU/L, ALT 117 IU/L, and HBsAg and HCV Ab negative. The abdominal US showed features suggestive of fatty liver.

Although his repeat urea breath test after 4 weeks of triple therapy completion was negative, he remained to have heartburn and was kept on omeprazole $20 \mathrm{mg}$ daily with significant improvement.

Additional investigations revealed ferritin $764 \mu \mathrm{g} / \mathrm{L}$, alpha1-antitrypsin $1.33 \mathrm{~g} / \mathrm{L}$, SMA screen, AMA screen, and LKM Abs were all negative, serum ceruloplasmin $0.06 \mathrm{~g} / \mathrm{L}$ (low), serum copper $272 \mu \mathrm{g} / \mathrm{L}$ (low; ref: 794-2,023), and 24-h urine copper $210 \mu \mathrm{g} / \mathrm{L}$ (high). The patient was advised to follow a low-copper diet (avoiding mushrooms, nuts, dried fruits, liver, and shellfish) for 6 weeks before repeating the copper level. The penicillamine test with 24-h urine copper was positive. His repeat serum copper level was $268 \mu \mathrm{g} / \mathrm{L}$ (low; ref: 794-2,023) and 24-h urine copper $136 \mu \mathrm{g} / \mathrm{L}$ (high).

He was referred to an ophthalmologist to verify the presence of KF rings, which was negative. He was also assessed by a neurologist for evaluation of any neurological signs complicating WD; surprisingly, the patient did not show any signs of neurological complications of the disease, such as tremors or chorea.

In October 2017, the patient underwent liver biopsy, and the histopathology report was suggestive of moderate chronic hepatitis with failure to stain copper and copper-associated protein, however, quantitative copper assay was $183 \mu \mathrm{g} / \mathrm{g}$. Steatosis was present in $>80 \%$ of the biopsies, modified histological activity index grading was Grade 4, modified staging: Stage I.

He had a follow-up appointment in October 2017, WD scoring system was done and reported 8, which is supportive of the established diagnosis.

ATP7B gene test and magnetic retrograde cholangiopancreatography (MRCP) were requested. The MRCP reported no intrahepatic or extrahepatic bile duct dilatation. Common bile duct was $2 \mathrm{~mm}$ in diameter. There were no stones in the common bile duct, and he had a welldistended gallbladder. There was a tiny 2-mm benign lesion in segment 7 of the liver, but no

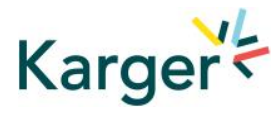




\section{Case Reports in Gastroenterology}

Case Rep Gastroenterol 2021;15:142-146 DOI: $10.1159 / 000512422$

(c) 2021 The Author(s). Published by S. Karger AG, Basel www.karger.com/crg

AIDhaleei et al.: Wilson's Disease Presenting in Late Adult Life

other lesions in the liver. There was a normal pancreatic duct. Both adrenals, kidneys, and spleen appeared normal. Genetic testing (using next-generation sequencing) showed homozygote for $\mathrm{c} 3236 \mathrm{G}>\mathrm{C}$ in the ATP7B gene.

The patient was started on penicillamine $250 \mathrm{mg}$ daily in December 2018 for 2 weeks. The dose and frequency of penicillamine were increased in the subsequent visit to $500 \mathrm{mg}$ twice daily and were tolerated by the patient. After commencing the therapy, his liver enzymes improved to AST $39 \mathrm{IU} / \mathrm{L}$ and ALT $80 \mathrm{IU} / \mathrm{L}$.

\section{Discussion}

WD is an autosomal recessive disorder caused by a mutation in the ATP7B gene on chromosome 13 leading to a defective copper transport protein synthesis (ceruloplasmin) [5]. This results in pathological copper metabolism and excessive copper overload [6]. Abnormal copper deposition occurs primarily in hepatic tissues followed by the central nervous system and cornea. Other organs can also be involved although less described [7]. WD can occur at any age but most commonly during the second and third decades of life [8]. We are reporting a patient in his fifth decade of life who was referred to our gastroenterology clinic with abnormal liver function tests and fatty liver seen on the US abdomen.

Hepatic manifestations of WD can range from acute hepatitis to fulminant liver failure with signs of decompensated liver cirrhosis [9]. Neurological symptoms may present as tremors, dystonia, choreoathetosis, mood changes, and dementia [10].

$\mathrm{KF}$ rings have been described as greenish-brown discoloration of the corneal margin and are pathognomonic for WD. KF rings have been reported in approximately half of the cases with hepatic manifestation, however, it is seen in almost all patients with neurological manifestations [11]. Ferenci et al. [12] presented a large multinational study on genotype-phenotype correlations in WD and investigated symptomatic patients above 40 years; the majority of patients had central nervous system disease, followed by hepatic manifestations, and only 2 were asymptomatic. Yousefi et al. [13] reported a case of WD from the Middle East, with lateadulthood onset, hepatic encephalopathy, and cirrhosis without ophthalmological manifestations. Our patient had impaired liver function tests, but neither neuropsychiatric nor ocular manifestations/findings were identified.

Investigations of WD include both clinical and biochemical tests [12]. A liver biopsy for copper quantity and histology is recommended if clinical and biochemical tests are nonconclusive. A copper concentration amount below $250 \mu \mathrm{g} / \mathrm{g}$ dry weight in a liver biopsy necessitates further diagnostic evaluation with a molecular test [14]. In our case, the patient had a low level of ceruloplasmin, with elevated 24-h urinary copper excretion; liver biopsy showed a copper quantitative result of $183 \mu \mathrm{g} / \mathrm{g}$. The diagnosis of WD in our patient was confirmed by a positive genetic test.

Management of symptomatic WD patients involves long-term copper-chelating agents, such as penicillamine, trientine hydrochloride, and zinc replacement; however, liver transplant remains the treatment of choice [15]. Our patient was started on penicillamine and has continued to do well since then.

In summary, WD is a relatively rare genetic disorder associated with hepatic, neurological, and ophthalmic complications. Our case highlights the diagnosis of WD despite the lack of supporting clinical manifestations. Early diagnosis will delay the occurrence of complications like liver failure.

\section{Karger'=}




\section{Patient Perspective}

I am pleased that the doctors in this institute knew my disease early on and started me on the right treatment that would prevent any complications.

\section{Acknowledgement}

The authors would like to thank the patient for his contribution.

\section{Statement of Ethics}

Written informed consent was obtained from the patient for publication of this case report.

\section{Conflict of Interest Statement}

The authors declare that they have no conflicts of interest.

\section{Funding Sources}

The authors declare that there was no funding for this research.

\section{Author Contributions}

W.A. wrote the case report and introduction. M.A. reviewed the literature and wrote the discussion. I.A. reviewed the manuscript and revised it.

\section{References}

1 Mak CM, Lam CW. Diagnosis of Wilson's disease: a comprehensive review. Crit Rev Clin Lab Sci. 2008;45(3):263-90.

2 Liu G, Ma D, Cheng J, Zhang J, Luo C, Sun Y, et al. Identification and characterization of a novel 43-bp deletion mutation of the ATP7B gene in a Chinese patient with Wilson's disease: a case report. BMC Med Genet. 2018 Apr;19(1):61.

3 Huong NT, Lien NT, Ngoc ND, Mai NT, Hoa NP, Hai LT, et al. Three novel mutations in the ATP7B gene of unrelated Vietnamese patients with Wilson disease. BMC Med Genet. 2018 Jun;19(1):104.

4 Daneshjoo 0, Garshasbi M. Novel compound heterozygote mutations in the ATP7B gene in an Iranian family with Wilson disease: a case report. J Med Case Reports. 2018 Mar;12(1):68.

5 Stenson PD, Mort M, Ball EV, Evans K, Hayden M, Heywood S, et al. The Human Gene Mutation Database: towards a comprehensive repository of inherited mutation data for medical research, genetic diagnosis and next-generation sequencing studies. Hum Genet. 2017 Jun;136(6):665-77.

6 Roberts EA, Schilsky ML; American Association for Study of Liver Diseases (AASLD). Diagnosis and treatment of Wilson disease: an update. Hepatology. 2008 Jun;47(6):2089-111. 


\section{Case Reports in Gastroenterology}

7 Dzieżyc K, Litwin T, Członkowska A. Other organ involvement and clinical aspects of Wilson disease. In: Członkowska A, Schilsky M, editors. Handbook of clinical neurology. Vol. 142. Wilson disease. Elsevier; 2017 Jan 1. p. 157-169. https://doi.org/10.1016/B978-0-444-63625-6.00013-6.

8 Merle U, Schaefer M, Ferenci P, Stremmel W. Clinical presentation, diagnosis and long-term outcome of Wilson's disease: a cohort study. Gut. 2007 Jan;56(1):115-20.

9 Kamath PS, Kim WR; Advanced Liver Disease Study Group. The model for end-stage liver disease (MELD). Hepatology. 2007 Mar;45(3):797-805.

10 Bandmann O, Weiss KH, Kaler SG. Wilson's disease and other neurological copper disorders. Lancet Neurol. 2015 Jan;14(1):103-13.

11 Rodrigo Agudo JL, Valdés Mas M, Vargas Acosta AM, Ortiz Sánchez ML, Gil del Castillo ML, Carballo Alvarez LF, et al. [Clinical presentation, diagnosis, and long-term outcome of 29 patients with Wilson's disease]. Rev Esp Enferm Dig. 2008 Aug;100(8):456-61.

12 Ferenci P, Członkowska A, Merle U, Ferenc S, Gromadzka G, Yurdaydin C, et al. Late-onset Wilson's disease. Gastroenterology. 2007 Apr;132(4):1294-8.

13 Yousefi M, Yousefi M, Gharravi AM. Late-onset Wilson disease in older patient without ophthalmological findings, a case report. Clin Case Rep. 2019 May;7(6):1253-8.

14 European Association for Study of Liver. EASL clinical practice guidelines: wilson's disease. J Hepatol. 2012 Mar;56(3):671-85.

15 Ala A, Walker AP, Ashkan K, Dooley JS, Schilsky ML. Wilson's disease. Lancet. 2007 Feb;369(9559):397-408.

Our case has been accepted in the united European Gastroenterology (UEG) Week in 2020 for poster presentation. 